\title{
Low cadmium application increase miscanthus growth and cadmium translocation
}

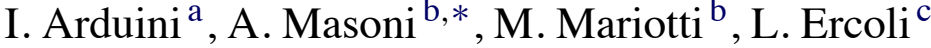 \\ a Dipartimento di Scienze Botaniche, Università di Pisa, Via Luca Ghini 5, I-56126 Pisa, Italy \\ ${ }^{\mathrm{b}}$ Dipartimento di Agronomia e Gestione dell'Agroecosistema, Università di Pisa, Via S. Michele degli Scalzi 2, I-56124 Pisa, Italy \\ c Scuola Superiore Sant'Anna di Studi Universitari e di Perfezionamento, Piazza Martiri della Libertà 33, I-56127 Pisa, Italy
}

Accepted 9 January 2004

\begin{abstract}
Plants of miscanthus were grown in nutrient solution supplied with $0,0.25,0.50$, and $0.75 \mathrm{mg}^{-1}$ cadmium and were harvested after 1 and 3 months of treatment. With cadmium up to $0.50 \mathrm{mg}^{-1}$ biomass of secondary culms and roots was increased at both harvests, whereas biomass of the main culm and the rhizome was slightly increased at the first harvest and decreased at the second. With $0.75 \mathrm{mg}^{-1} \mathrm{Cd}$ biomass of all plant parts except roots was decreased at both harvests. The biomass of the entire plant was always higher than in controls with 0.25 and $0.50 \mathrm{mg} \mathrm{l}^{-1} \mathrm{Cd}$ and lower with $0.75 \mathrm{mg}^{-1} \mathrm{Cd}$. Relative growth rates (RGRs) showed that the two lower Cd levels stimulated growth only during the first growth period, whereas during the second they reduced growth of the main culm and the rhizome and did not affect that of secondary culms and roots. Root morphology changed with $0.75 \mathrm{mg} \mathrm{l}^{-1} \mathrm{Cd}$ : length, surface, and volume drastically decreased, whereas dry weight was not affected and root average diameter increased. All Cd levels decreased specific dry weight increment (SDWI) but did not affect the (net uptake rates) NUR of nitrogen and the N-concentration of different plant parts. Roots showed the highest Cd-concentrations at both harvests and with all Cd levels, and leaves the lowest. The Cd-concentration of aerial plant parts was highest with $0.50 \mathrm{mg}^{-1}$ $\mathrm{Cd}$ and lowest with $0.75 \mathrm{mg} \mathrm{l}^{-1}$, whereas that of roots increased with $\mathrm{Cd}$ supply. Between the first and the second harvest the $\mathrm{Cd}$-concentration of roots, rhizome, and main culm increased only with the highest Cd-level, whereas that of leaves and secondary culms with all levels. The Cd-NUR was linearly related to the concentration of the metal in the nutrient solution during the first month of application and was very low during the following two. Above summarized patterns suggest that cadmium flows passively into roots but the saturation of binding sites limits its uptake. The metal is slowly translocated to the shoot due to mechanisms that restrict internal Cd-transport. This regulation is partially disrupted with $0.75 \mathrm{mg}^{-1} \mathrm{Cd}$ but translocation to aerial organs is still restricted probably due to reduced transpiration. In this research, the maximum Cd-content achieved by miscanthus was $3.8 \mathrm{mg}$ per plant after a 3-month treatment with $0.75 \mathrm{mg}^{-1} \mathrm{Cd}$, but the maximum content of the shoot was $1 \mathrm{mg}$ per plant and was obtained with $0.50 \mathrm{mg} 1^{-1} \mathrm{Cd}$.
\end{abstract}

(c) 2004 Elsevier B.V. All rights reserved.

Keywords: Cadmium; Growth; Miscanthus; Cd-uptake; Phytoremediation

\section{Introduction}

* Corresponding author.

Cadmium is a relatively rare metal in natural environments, but its distribution has increased during 
the last century due to human activities. Anthropogenic inputs of cadmium to soils occur via shortor long-range atmospheric deposition, additions in fertilizers/manures, municipal sewage-wastes and composts, and industrial sludges (Grant et al., 1998; McLaughlin et al., 1999). Cadmium is readily taken up by plants, but unlike other heavy metals, it is not phytotoxic at the low concentrations that already pose concern from a human health viewpoint (McLaughlin et al., 1999). To humans, cadmium compounds are, indeed, well-known carcinogens inducing tumors in lung, tests, and prostate (International Agency for Research on Cancer, 1993). Moreover, low-level exposure to this metal is also associated to renal dysfunction, pulmonary emphysema and bone demineralization (World Bank Group, 1999). Grant et al. (1998) report that durum wheat, flax, sunflowers, and potatoes grown on slightly contaminated soils can accumulate amounts of cadmium which exceed current and proposed maximum $\mathrm{Cd}$-concentrations acceptable for human intake.

Phytoremediation, i.e. the use of accumulator plants to remove cadmium from agricultural soils, has been proposed as a possible technique to reduce the risk of crop contamination (Salt et al., 1998; Arduini and Masoni, 2002). For phytoremediation high biomass yielding plants are to be chosen, which are able to transfer the heavy metal efficiently and rapidly from soil via the root system to the aerial part that, thereafter, will be harvested and disposed. Root to shoot translocation of incorporated metals is recognized as one of the major limiting steps at the plant level for reaching promising cleanup results (Schneider et al., 1999). The percentage of total cadmium taken up by the plant that is allocated in the top parts is found to be relatively low in most species and to decrease markedly with the increase of Cd supply (Hardiman et al., 1984; Barbolani et al., 1986; Florijn and Van Beusichem, 1993). However, most studies of Cd-uptake and accumulation in plants to date have used high-level $\mathrm{Cd}$ exposure for a short time to elicit responses, levels far above those encountered in agricultural production (Wagner, 1993; Sanità di Toppi and Gabbrielli, 1999). Such levels of cadmium immediately affect plant-water relationships through the alteration of the permeability of root membranes and the decrease of transpiration flow (Hernández et al., 1998; Haag-Kerwer et al., 1999). Both phenom- ena strongly reduce plant growth and the transport of mineral elements, i.e. nutrients and cadmium, to the shoot (Varga et al., 1999), and thus decrease the ability of plants to uptake metals and to translocate them to above-ground parts. Moreover, short-term exposure to toxic metal levels does not allow to observe recovery from stress or uptake saturation phenomena. From most data available in literature it is, therefore, difficult to predict the amount of cadmium a plant is able to accumulate in the shoot when grown for a long time at non-toxic cadmium levels.

Starting from the conclusions of Florijn and Van Beusichem (1993) that the Cd-concentration in the shoot is determined by its concentration in roots and by the amounts loaded into the xylem, and considering that increasing $\mathrm{Cd}$ supply increases the former but reduces the latter, however, it is reasonable to suggests that phytoextraction results could be improved with conditions that increase Cd-uptake of roots without inducing toxic effects, such as prolonged applications of low Cd levels.

Miscanthus is a vigorous perennial Gramineae species, which reproduces vegetatively by rhizomes. It originates from East Asia, but its cultivation as energy crop has been promoted throughout Europe since the 1990s, with dry matter yields ranging from 25 to $35 \mathrm{tha}^{-1}$ per year. In Central Italy miscanthus was able to produce more than $35 \mathrm{tha}^{-1}$ per year of aerial dry matter over a period of 4 years (Ercoli et al., 1999). The root system plays a major role in determining the phytoextraction performance of a species. Roots of an established miscanthus crop were found to reach a maximum depth of $250 \mathrm{~cm}$ and a dry weight of over $10 \mathrm{tha}^{-1}$ (Neukirchen et al., 1999). In a previous research carried out on miscanthus, we found that growth of this species was reduced with cadmium concentrations equal or higher than $0.75 \mathrm{mg} \mathrm{l}^{-1}$ and that the cadmium concentration and content of the aerial part decreased with increasing level of this metal in the nutrient solution (Arduini et al., 2003).

The present work aims to elucidate the influence of low levels of cadmium and of time of exposure on miscanthus growth and Cd-uptake and translocation patterns. In order to do that, plants of Miscanthus sinensis L. var. Giganteus were grown for 1 and 3 months in nutrient solution supplied with $0,0.25,0.50$, and $0.75 \mathrm{mg} \mathrm{l}^{-1} \mathrm{Cd}$. 


\section{Materials and methods}

\subsection{Plant material and culture conditions}

At the end of winter rhizomes of M. sinensis L. var. Giganteus (Greef and Deuter, 1993) were collected in the field from an 8-year-old crop, cut into pieces of about $5 \mathrm{~g}$ fresh weight and placed in pots filled with sand. Pots were placed in a greenhouse and regularly watered. One month later (15 April), plants that were about $20 \mathrm{~cm}$ tall were transferred to an open-air hydroponics installation equipped for the nutrient film technique. The circulating nutrient solution was arranged following Clark (1982) with slight modifications. Ion concentrations in the solution (all the following expressed in $\mathrm{mgl}^{-1}$ ) were $\mathrm{NO}_{3}-\mathrm{N}, 351$; $\mathrm{Ca}$, 302.4; K, 283; S, 192; $\mathrm{NH}_{4}-\mathrm{N}, 128 ; \mathrm{Cl}, 65 ; \mathrm{Mg}, 37.8$; $\mathrm{Na}, 4.56$; Fe, 4; P, 2; Mn, 0.974; B, 0.536; Zn, 0.3; $\mathrm{Cu}, 0.076$; Mo, 0.155. The $\mathrm{pH}$ was 7.5 and conductivity $3.8 \mathrm{mS} \mathrm{cm}^{-1}$. Evaporated and transpired water was continuously replaced with tap water and the nutrient solution was completely renewed every 2 weeks.

After a 4-week plant acclimation, cadmium was added to the nutrient solution as nitrate salt to final concentrations of 0 (control), 0.25, 0.5, and $0.75 \mathrm{mg} \mathrm{l}^{-1}$. Each Cd-treatment was comprised of 16 plants spaced at $50 \mathrm{~cm}$ intervals, thus simulating a field density of 4 plants $\mathrm{m}^{-2}$.

Four plants per treatment were harvested just before cadmium addition (0 days after treatment, DAT), 1 month later (29 DAT), and when all control plants were at the end of the heading stage (93 DAT).

\subsection{Growth measurements}

Harvested plants were divided into main culm, that was the only one present at the beginning of cadmium treatment, secondary culms, rhizome, and roots. Roots were generously rinsed with tap water to remove $\mathrm{Cd}$ deposits and a root sample from each plant was deep-frozen for later estimation of root length, area, and average diameter. For dry weight determination, all plant parts were dried at $75^{\circ} \mathrm{C}$ to constant weight. To determine root size parameters, the deep-frozen root samples were stepwise brought back to room temperature. For each sample, three subsamples of about $1 \mathrm{~g}$ fresh weight were weighed, cut into pieces of less than $10 \mathrm{~cm}$, and distributed on a glass Petri dish of
$20 \mathrm{~cm}$ diameter avoiding overlapping. Length and area of each root subsample were determined with a Leica Quantimet 500 image analyzer and their average diameter was estimated dividing area by length. Root surface was estimated after Kokko et al. (1993), as

root surface $=\pi \times$ root area

Assuming that root systems are equivalent to cylinders which diameter $(d)$ corresponds to the root average diameter and which height $(h)$ corresponds to total root length, root volume was estimated as

root volume $=\pi\left(\frac{d}{2}\right)^{2} h$

\subsection{Chemical analyses}

Total nitrogen was determined by the microKjeldahl method on dried plant parts ground to pass through a 40-mesh stainless steel screen. Cadmium concentration was determined by atomic absorption spectrometry (GBC 903 Single Beam, Australia) on ground samples $(0.5 \mathrm{~g})$ that were overnight predigested in $5 \mathrm{ml}$ concentrated $\mathrm{HNO}_{3}$, and then digested adding $1 \mathrm{ml}$ $\mathrm{HClO}_{4}$ at $220^{\circ} \mathrm{C}$ in an aluminum block digestor (Tecator $\mathrm{ab}$, Sweden).

\subsection{Calculation of indexes and statistics}

For the periods between successive harvests and for the whole treatment period the following indexes were calculated.

The relative growth rates (RGRs) of all plant parts, as

$\mathrm{RGR}=\frac{\ln W_{2}-\ln W_{1}}{t_{2}-t_{1}}$

where $W$ is the dry biomass at the beginning $\left(W_{1}\right)$ and at the end $\left(W_{2}\right)$ of each period, and $t_{2}-t_{1}$ is the duration of the period.

The specific dry weight increment (SDWI) was determined after Engels (1993), as

$\mathrm{SDWI}=\frac{S_{2}-S_{1}}{t_{2}-t_{1}} \frac{\ln \left(\mathrm{Rs}_{2} / \mathrm{Rs}_{1}\right)}{\mathrm{Rs}_{2}-\mathrm{Rs}_{1}}$

where $S$ is the dry weight of the shoot, Rs the dry weight of the root at the beginning (1) and at the end 
(2) of each period, and $t_{2}-t_{1}$ is the duration of the period.

The net uptake rates of $\mathrm{N}$ and $\mathrm{Cd}$ were determined following Engels (1993), as

$\mathrm{NUR}=\frac{\mathrm{Pc}_{2}-\mathrm{Pc}_{1}}{t_{2}-t_{1}} \frac{\ln \left(\mathrm{Rs}_{2} / \mathrm{Rs}_{1}\right)}{\mathrm{Rs}_{2}-\mathrm{Rs}_{1}}$

where $\mathrm{Pc}$ is the $\mathrm{N}$, or $\mathrm{Cd}$, content of the whole plant, and Rs is the dry weight of the root at the beginning (1) and at the end (2) of each period, and $t_{2}-t_{1}$ is the duration of the period.

The net translocation rates (NTR) were determined for the $\mathrm{N}$, or Cd, translocation from roots to aerial part, from roots to rhizome, and from rhizome to aerial part, as

$\mathrm{NTR}=\frac{\mathrm{Sn}_{2}-\mathrm{Sn}_{1}}{t_{2}-t_{1}} \frac{\ln \left(\mathrm{Su}_{2}\right)-\ln \left(\mathrm{Su}_{1}\right)}{\mathrm{Su}_{2}-\mathrm{Su}_{1}}$

In the formula $\mathrm{Sn}$ is the $\mathrm{N}$ - or $\mathrm{Cd}$-content of the sink, and $\mathrm{Su}$ is the $\mathrm{N}$ - or $\mathrm{Cd}$-content of the source, at the beginning $\left(\mathrm{Sn}_{1}\right.$ and $\left.\mathrm{Su}_{1}\right)$ and at the end $\left(\mathrm{Sn}_{2}\right.$ and $\mathrm{Su}_{2}$ ) of each treatment period, and $t_{2}-t_{1}$ is the duration of the period.

Data were analyzed with standard split-plot analysis of variance techniques to test effects of $\mathrm{Cd}$ level and duration of treatment. Significantly different means were separated at 0.05 probability level by the least significant difference test (Steel et al., 1997).

\section{Results}

\subsection{Plant growth}

The dry weight of plants grown with 0.25 and $0.50 \mathrm{mg} \mathrm{l}^{-1} \mathrm{Cd}$ was higher than that of control plants at both harvests, but the difference in dry weight between Cd-treated and not treated plants was lower at the end of the second growth period compared to the first one (Table 1). The RGR of the entire plant confirmed that the positive effect of low $\mathrm{Cd}$ levels occurred only during the first month of treatment, whereas during the following period all Cd-concentrations reduced the daily increment of biomass, without any difference between Cd levels. (Table 2). Plants grown with $0.75 \mathrm{mg} \mathrm{l}^{-1} \mathrm{Cd}$ showed significantly reduced biomass at both harvests and lower RGRs during both growth periods.
After the first month of treatment, cadmium did not affect significantly main culm height and biomass, whereas after 3 months it reduced main culm height and biomass with the highest $\mathrm{Cd}$ supply (Table 1). Cadmium concentrations up to $0.50 \mathrm{mg} \mathrm{l}^{-1}$ did not affect the initiation of new culms, whereas $0.75 \mathrm{mg} \mathrm{l}^{-1} \mathrm{Cd}$ reduced it slightly, and it is noteworthy that only plants grown with the two lower cadmium levels produced new culms between the first and the second harvest (Table 1). Moreover, these Cd-concentrations markedly stimulated growth of secondary culms during the first growth period (Table 2), so that their biomass was increased by $42 \%$ at the end of the experiment. Above data summarized, Cd-concentrations up to $0.50 \mathrm{mg} \mathrm{l}^{-1}$ increased aerial part biomass at both harvests, whereas $0.75 \mathrm{mg} \mathrm{l}^{-1} \mathrm{Cd}$ reduced it after 3 months of treatment (Table 1).

During the first treatment period, the two lower Cd-concentrations stimulated growth of rhizome and especially of roots and the highest decreased it, whereas during the second period all Cd-concentrations reduced RGR of the rhizome, but did not affect that of roots (Table 2). Thus, at the end of experiment, rhizome dry weight decreased at increasing $\mathrm{Cd}$ supply, whereas root dry weight was increased by $76 \%$ up to $0.50 \mathrm{mgl}^{-1} \mathrm{Cd}$ and decreased by $20 \%$ with $0.75 \mathrm{mgl}^{-1} \mathrm{Cd}$ (Table 1 ). As a result, the dry weight of the hypogeal plant part was not affected by cadmium up to $0.50 \mathrm{mg}^{-1}$ and was reduced by $37 \%$ with $0.75 \mathrm{mg} \mathrm{l}^{-1} \mathrm{Cd}$. Cadmium affected biomass partitioning between hypogeal organs in that it increased allocation of resources to roots rather than to the rhizome. As a result, the rhizome to root biomass ratio was 2 with the two lower $\mathrm{Cd}$ levels and approximately 3 with the highest one at both harvests, whereas in control plants it increased from 3 to 4.2 between the first and the second harvest.

\subsection{Root morphology and efficiency}

The two lower Cd-concentrations $(0.25$ and $0.50 \mathrm{mg}^{-1}$ ) increased root length, surface, and volume compared to control plants, with differences that were significant only after 3 months of treatment (Table 3). In contrast, the highest Cd-concentration, $0.75 \mathrm{mg}^{-1}$, markedly reduced former growth 
Table 1

Growth of miscanthus plants treated for 29 and 93 days with different cadmium concentrations

\begin{tabular}{|c|c|c|c|c|c|c|c|c|c|c|}
\hline \multirow{2}{*}{$\begin{array}{l}\text { DAT } \\
\text { (days) }\end{array}$} & \multirow{2}{*}{$\begin{array}{l}\text { Cadmium } \\
\text { supply } \\
\left(\mathrm{mg} \mathrm{l}^{-1}\right)\end{array}$} & \multirow{2}{*}{$\begin{array}{l}\text { Main culm } \\
\text { height }(\mathrm{cm})\end{array}$} & \multirow{2}{*}{$\begin{array}{l}\text { Culm number } \\
\text { (number per } \\
\text { plant) }\end{array}$} & \multicolumn{7}{|c|}{ Dry weight (gram per plant) } \\
\hline & & & & Main culm & $\begin{array}{l}\text { Secondary } \\
\text { culms }\end{array}$ & Aerial part & Rhizome & Roots & Hypogeal part & Entire plant \\
\hline 0 & 0 & $25.3 \pm 0.8 \mathrm{a}$ & $4 \pm 0.6 \mathrm{a}$ & $3.2 \pm 0.3 \mathrm{a}$ & $1.4 \pm 0.5 \mathrm{a}$ & $4.6 \pm 0.5 \mathrm{a}$ & $1.5 \pm 0.2 \mathrm{a}$ & $2.0 \pm 0.6 \mathrm{a}$ & $3.5 \pm 0.7 \mathrm{a}$ & $8.1 \pm 1.0 \mathrm{a}$ \\
\hline 29 & $\begin{array}{l}0 \\
0.25 \\
0.50 \\
0.75\end{array}$ & $\begin{array}{l}36.0 \pm 2.0 \mathrm{bc} \\
39.8 \pm 1.7 \mathrm{bcd} \\
37.3 \pm 1.4 \mathrm{bc} \\
35.7 \pm 1.8 \mathrm{~b}\end{array}$ & $\begin{aligned} 12 & \pm 0.9 \mathrm{~cd} \\
10 & \pm 1.0 \mathrm{bc} \\
10 & \pm 0.8 \mathrm{bc} \\
9 & \pm 0.5 \mathrm{~b}\end{aligned}$ & $\begin{array}{l}6.8 \pm 0.7 \mathrm{~b} \\
7.8 \pm 0.4 \mathrm{~b} \\
7.7 \pm 0.5 \mathrm{~b} \\
6.5 \pm 0.3 \mathrm{~b}\end{array}$ & $\begin{aligned} 6.9 & \pm 1.0 \mathrm{bc} \\
10.0 & \pm 1.0 \mathrm{~d} \\
9.4 & \pm 1.1 \mathrm{~cd} \\
5.9 & \pm 0.7 \mathrm{~b}\end{aligned}$ & $\begin{array}{l}13.7 \pm 1.0 \mathrm{~b} \\
17.8 \pm 0.8 \mathrm{c} \\
17.1 \pm 1.1 \mathrm{c} \\
12.4 \pm 0.7 \mathrm{~b}\end{array}$ & $\begin{array}{l}15.2 \pm 1.0 \mathrm{c} \\
18.7 \pm 1.6 \mathrm{~d} \\
18.4 \pm 2.2 \mathrm{~cd} \\
11.7 \pm 1.1 \mathrm{~b}\end{array}$ & $\begin{array}{l}5.1 \pm 0.7 \mathrm{~b} \\
9.2 \pm 1.4 \mathrm{c} \\
9.2 \pm 0.5 \mathrm{c} \\
4.2 \pm 0.6 \mathrm{~b}\end{array}$ & $\begin{array}{l}20.3 \pm 2.0 \mathrm{c} \\
27.9 \pm 1.3 \mathrm{~d} \\
27.6 \pm 1.8 \mathrm{~d} \\
15.9 \pm 0.5 \mathrm{~b}\end{array}$ & $\begin{array}{l}34.0 \pm 1.8 \mathrm{c} \\
45.7 \pm 2.3 \mathrm{~d} \\
44.7 \pm 2.5 \mathrm{~d} \\
28.4 \pm 1.7 \mathrm{~b}\end{array}$ \\
\hline 93 & $\begin{array}{l}0 \\
0.25 \\
0.50 \\
0.75\end{array}$ & $\begin{array}{l}44.2 \pm 0.9 \mathrm{~d} \\
40.3 \pm 0.4 \mathrm{~cd} \\
43.5 \pm 2.0 \mathrm{~d} \\
35.8 \pm 1.5 \mathrm{~b}\end{array}$ & $\begin{aligned} 12 & \pm 0.7 \mathrm{~cd} \\
13 & \pm 0.9 \mathrm{~d} \\
13 & \pm 1.0 \mathrm{~d} \\
9 & \pm 0.9 \mathrm{~b}\end{aligned}$ & $\begin{aligned} 11.7 & \pm 0.6 \mathrm{c} \\
10.1 & \pm 0.4 \mathrm{c} \\
9.9 & \pm 0.5 \mathrm{bc} \\
7.9 & \pm 0.9 \mathrm{~b}\end{aligned}$ & $\begin{array}{l}15.8 \pm 1.5 \mathrm{e} \\
21.6 \pm 0.9 \mathrm{ef} \\
23.1 \pm 1.0 \mathrm{f} \\
12.4 \pm 1.8 \mathrm{~d}\end{array}$ & $\begin{array}{l}27.5 \pm 1.3 \mathrm{e} \\
31.7 \pm 0.7 \mathrm{f} \\
33.0 \pm 1.1 \mathrm{f} \\
20.3 \pm 1.5 \mathrm{~d}\end{array}$ & $\begin{array}{l}30.9 \pm 2.5 \mathrm{f} \\
27.4 \pm 1.5 \mathrm{e} \\
25.0 \pm 1.2 \mathrm{e} \\
18.4 \pm 1.9 \mathrm{~cd}\end{array}$ & $\begin{aligned} 7.4 & \pm 0.6 \mathrm{c} \\
13.0 & \pm 1.0 \mathrm{~d} \\
12.9 & \pm 1.1 \mathrm{~d} \\
5.9 & \pm 0.8 \mathrm{bc}\end{aligned}$ & $\begin{array}{l}38.3 \pm 3.1 \mathrm{e} \\
40.4 \pm 2.8 \mathrm{e} \\
37.9 \pm 2.5 \mathrm{e} \\
24.3 \pm 1.2 \mathrm{~cd}\end{array}$ & $\begin{array}{l}65.8 \pm 6.1 \mathrm{e} \\
72.1 \pm 4.7 \mathrm{f} \\
70.9 \pm 3.2 \mathrm{f} \\
44.6 \pm 2.7 \mathrm{~d}\end{array}$ \\
\hline
\end{tabular}

Data are means \pm standard errors of four replicates. Values in each column followed by the same letter are not significantly different at $P=0.05$ as determined by the Duncan's test. 
Table 2

Relative growth rate of miscanthus plants during the first (0-29 DAT) and the second (30-93 DAT) period of growth in nutrient solution supplied with different cadmium concentrations

\begin{tabular}{|c|c|c|c|c|c|c|}
\hline \multirow{2}{*}{$\begin{array}{l}\text { Growth period } \\
\text { (DAT) }\end{array}$} & \multirow{2}{*}{$\begin{array}{l}\text { Cadmium supply } \\
\left(\mathrm{mg} \mathrm{l}^{-1}\right)\end{array}$} & \multicolumn{5}{|c|}{ Relative growth rate $\left(\mathrm{mg} \mathrm{g}^{-1}\right.$ per day) } \\
\hline & & Main culm & Secondary culms & Rhizome & Roots & Entire plant \\
\hline \multirow[t]{4}{*}{$0-29$} & 0 & $25.7 \pm 2.1 \mathrm{a}$ & $55.7 \pm 3.0 \mathrm{a}$ & $79.8 \pm 2.1 \mathrm{a}$ & $32.5 \pm 2.7 \mathrm{a}$ & $49.5 \pm 1.8 \mathrm{a}$ \\
\hline & 0.25 & $30.2 \pm 1.8 \mathrm{~b}$ & $68.6 \pm 2.7 \mathrm{~b}$ & $86.9 \pm 3.3 \mathrm{~b}$ & $52.6 \pm 3.5 \mathrm{~b}$ & $59.6 \pm 2.7 \mathrm{~b}$ \\
\hline & 0.50 & $29.9 \pm 1.6 \mathrm{~b}$ & $66.6 \pm 1.9 \mathrm{~b}$ & $86.4 \pm 2.9 \mathrm{~b}$ & $52.6 \pm 4.1 \mathrm{~b}$ & $58.9 \pm 2.1 \mathrm{~b}$ \\
\hline & 0.75 & $24.1 \pm 1.3 \mathrm{a}$ & $50.6 \pm 2.8 \mathrm{a}$ & $70.8 \pm 3.0 \mathrm{c}$ & $25.9 \pm 2.3 \mathrm{c}$ & $43.2 \pm 2.4 \mathrm{c}$ \\
\hline \multirow[t]{4}{*}{ 30-93 } & 0 & $8.5 \pm 0.7 \mathrm{c}$ & $13.0 \pm 1.2 \mathrm{c}$ & $11.1 \pm 1.5 \mathrm{~d}$ & $5.8 \pm 0.9 \mathrm{~d}$ & $10.3 \pm 0.5 \mathrm{~d}$ \\
\hline & 0.25 & $4.2 \pm 0.3 \mathrm{~d}$ & $12.8 \pm 0.9 \mathrm{c}$ & $6.0 \pm 1.2 \mathrm{de}$ & $5.4 \pm 1.2 \mathrm{~d}$ & $7.2 \pm 0.5 \mathrm{e}$ \\
\hline & 0.50 & $4.0 \pm 0.4 \mathrm{~d}$ & $14.0 \pm 1.0 \mathrm{c}$ & $4.8 \pm 0.9 \mathrm{e}$ & $5.2 \pm 1.1 \mathrm{~d}$ & $7.2 \pm 0.7 \mathrm{e}$ \\
\hline & 0.75 & $3.1 \pm 0.7 \mathrm{~d}$ & $11.5 \pm 1.1 \mathrm{c}$ & $7.0 \pm 1.0 \mathrm{de}$ & $5.2 \pm 1.3 \mathrm{~d}$ & $7.1 \pm 0.8 \mathrm{e}$ \\
\hline
\end{tabular}

Data are means \pm standard errors of four replicates. Values in each column followed by the same letter are not significantly different at $P=0.05$ as determined by the Duncan's test.

parameters at both harvests, but increased root average diameter. As a result, already after 1 month roots appeared shorter and thicker and the whole root system more dense and compact.

The specific dry weight increment, which calculates the daily increment of shoot biomass on each unit of root biomass, was not affected by cadmium during the first growth period and was reduced by $36 \%$ during the second, independently of Cd level (Fig. 1). Thus, longer $\mathrm{Cd}$ applications slightly reduced shoot growth compared to root growth suggesting that the efficiency of roots in supplying nutrients to the shoot was reduced.

\subsection{Nitrogen uptake}

Cadmium did not affect the net uptake rate of nitrogen and its concentration in different plant parts (data not reported). Thus, the different nitrogen content observed in response to cadmium was only a consequence of its influence on biomass production.

Over the whole duration of the Cd-treatment period, the nitrogen translocation from roots to rhizome was markedly reduced with all $\mathrm{Cd}$ levels and that from rhizome to aerial part was increased, so that the $\mathrm{N}$-translocation from roots to aerial part was not significantly changed by the metal (Fig. 2).

Table 3

Length, average diameter, surface and volume of miscanthus roots treated for 29 and 93 days with different cadmium concentrations

\begin{tabular}{|c|c|c|c|c|c|}
\hline \multirow{2}{*}{$\begin{array}{l}\text { DAT } \\
\text { (days) }\end{array}$} & \multirow{2}{*}{$\begin{array}{l}\text { Cadmium } \\
\text { supply }\left(\mathrm{mg}^{-1}\right)\end{array}$} & \multicolumn{4}{|l|}{ Root } \\
\hline & & Length (meter per plant) & Diameter (mm) & Surface $\left(\mathrm{dm}^{2}\right.$ per plant $)$ & Volume $\left(\mathrm{cm}^{3}\right.$ per plant $)$ \\
\hline 0 & 0 & $32.8 \pm 5.3 \mathrm{a}$ & $1.5 \pm 0.02 \mathrm{a}$ & $15.4 \pm 3.5 \mathrm{a}$ & $59.5 \pm 9.5 \mathrm{a}$ \\
\hline \multirow[t]{4}{*}{29} & 0 & $86.5 \pm 7.1 \mathrm{c}$ & $1.5 \pm 0.03 \mathrm{a}$ & $41.0 \pm 8.7 \mathrm{c}$ & $160.8 \pm 21.3 \mathrm{c}$ \\
\hline & 0.25 & $101.2 \pm 12.0 \mathrm{c}$ & $1.4 \pm 0.01 \mathrm{a}$ & $45.4 \pm 4.5 \mathrm{c}$ & $166.0 \pm 17.1 \mathrm{c}$ \\
\hline & 0.50 & $108.9 \pm 9.7 \mathrm{c}$ & $1.5 \pm 0.02 \mathrm{a}$ & $45.7 \pm 3.6 \mathrm{c}$ & $186.3 \pm 11.5 \mathrm{c}$ \\
\hline & 0.75 & $43.6 \pm 3.6 \mathrm{a}$ & $1.6 \pm 0.01 \mathrm{a}$ & $21.3 \pm 2.5 \mathrm{~b}$ & $83.2 \pm 6.2 \mathrm{~b}$ \\
\hline \multirow[t]{4}{*}{93} & 0 & $96.0 \pm 8.9 \mathrm{c}$ & $1.5 \pm 0.02 \mathrm{a}$ & $45.6 \pm 3.7 \mathrm{c}$ & $176.8 \pm 10.7 \mathrm{c}$ \\
\hline & 0.25 & $132.7 \pm 15.6 \mathrm{~d}$ & $1.4 \pm 0.02 \mathrm{a}$ & $60.4 \pm 6.1 \mathrm{~d}$ & $218.8 \pm 21.1 \mathrm{~d}$ \\
\hline & 0.50 & $151.8 \pm 13.2 \mathrm{~d}$ & $1.4 \pm 0.02 \mathrm{a}$ & $65.7 \pm 5.4 \mathrm{~d}$ & $228.7 \pm 19.5 \mathrm{~d}$ \\
\hline & 0.75 & $17.3 \pm 1.8 \mathrm{~b}$ & $1.9 \pm 0.02 \mathrm{a}$ & $10.1 \pm 0.9 \mathrm{a}$ & $47.7 \pm 4.2 \mathrm{a}$ \\
\hline
\end{tabular}

Data are means \pm standard errors of four replicates. Values in each column followed by the same letter are not significantly different at $P=0.05$ as determined by the Duncan's test. 


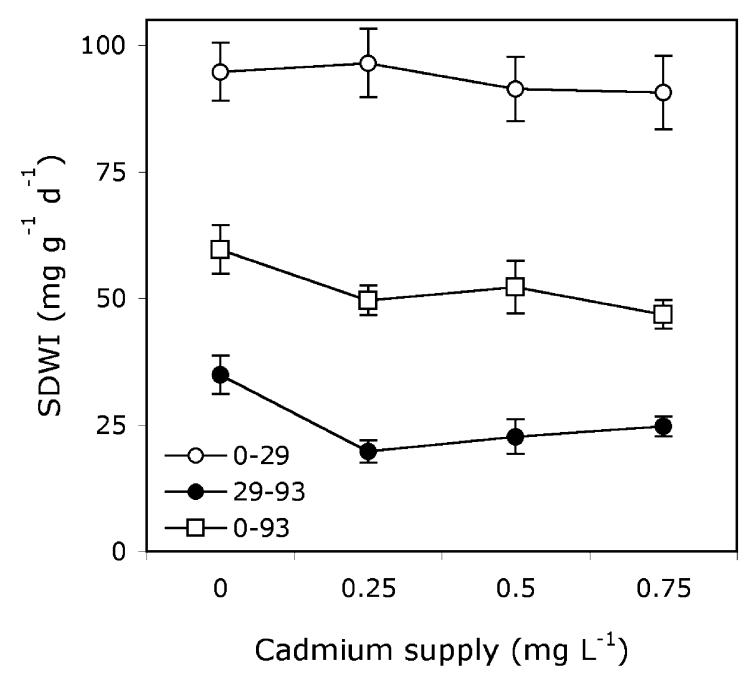

Fig. 1. Specific dry weight increment of miscanthus plants during the first (0-29 DAT) and the second (30-93 DAT) growth period, and during the whole Cd-treatment period (0-93 DAT). Bars represent standard errors (S.E.) of four replicates.

\subsection{Cadmium uptake and distribution}

Cadmium supply markedly increased the Cd-concentration of all plant parts (Table 4). Roots showed the highest Cd-concentrations at both harvests and at

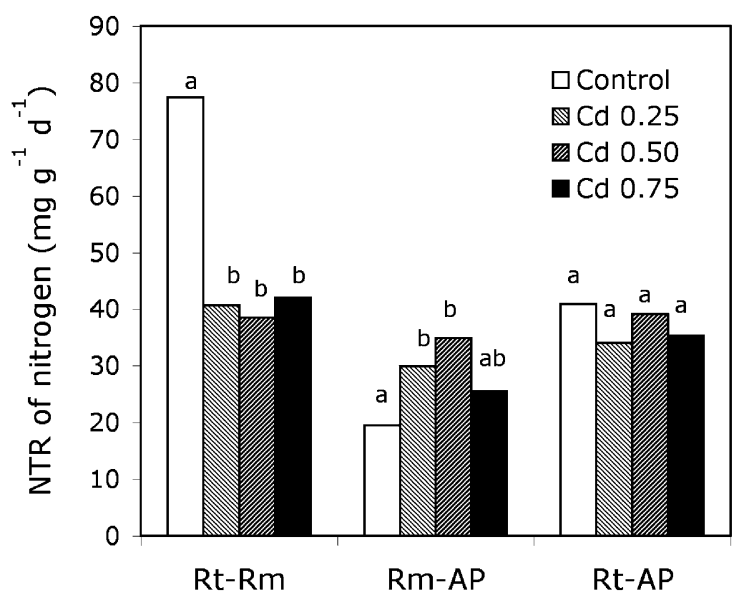

Fig. 2. Net translocation rate of nitrogen from roots to rhizome (Rt-Rm), from rhizome to aerial part (Rm-AP), and from roots to aerial part (Rt-AP) of miscanthus plants treated for 93 days with different cadmium concentrations $\left(\mathrm{mgl}^{-1}\right)$. Different letters among Cd-treatments indicate significant differences at $P=0.05$ as determined by the Duncan's test.

all Cd levels, and leaves the lowest. The plant part with the highest Cd-concentration after roots was the main culm up to $0.50 \mathrm{mgl}^{-1} \mathrm{Cd}$ and the rhizome at $0.75 \mathrm{mgl}^{-1} \mathrm{Cd}$. The Cd-concentration of belowground plant parts increased at increasing Cd supply,

Table 4

Cadmium concentration and cadmium content of the main culm and its leaves, secondary culms, rhizome, and roots of miscanthus plants treated for 29 and 93 days with different cadmium concentrations

\begin{tabular}{|c|c|c|c|c|c|c|}
\hline DAT (days) & $\begin{array}{l}\text { Cadmium supply } \\
\left(\mathrm{mg}^{-1}\right)\end{array}$ & Main culm & Main culm leaves & Secondary culms & Rizhome & Roots \\
\hline & & \multicolumn{5}{|c|}{ Cadmium concentration $\left(\mathrm{mg} \mathrm{kg}^{-1}\right)$} \\
\hline \multirow[t]{3}{*}{29} & 0.25 & $34.0 \pm 1.1 \mathrm{a}$ & $5.3 \pm 0.7 \mathrm{a}$ & $9.0 \pm 2.1 \mathrm{a}$ & $10.3 \pm 0.6 \mathrm{a}$ & $40.6 \pm 1.4 \mathrm{a}$ \\
\hline & 0.50 & $63.5 \pm 6.7 \mathrm{c}$ & $7.7 \pm 1.2 \mathrm{~b}$ & $15.9 \pm 2.2 \mathrm{~b}$ & $28.9 \pm 4.7 \mathrm{~b}$ & $98.1 \pm 15.2 \mathrm{~b}$ \\
\hline & 0.75 & $20.4 \pm 1.2 \mathrm{~b}$ & $1.7 \pm 0.2 \mathrm{e}$ & $7.3 \pm 0.6 \mathrm{a}$ & $36.4 \pm 5.8 \mathrm{c}$ & $289.5 \pm 22.9 \mathrm{c}$ \\
\hline \multirow[t]{4}{*}{93} & 0.25 & $38.7 \pm 0.7 \mathrm{a}$ & $10.1 \pm 0.7 \mathrm{c}$ & $14.7 \pm 0.1 \mathrm{~b}$ & $14.8 \pm 0.3 \mathrm{a}$ & $48.6 \pm 3.1 \mathrm{a}$ \\
\hline & 0.50 & $60.2 \pm 6.9 \mathrm{c}$ & $14.5 \pm 0.8 \mathrm{~d}$ & $28.4 \pm 2.1 \mathrm{c}$ & $26.6 \pm 1.6 \mathrm{~b}$ & $105.7 \pm 9.4 \mathrm{~b}$ \\
\hline & 0.75 & $40.3 \pm 7.5 \mathrm{a}$ & $8.3 \pm 1.8 \mathrm{bc}$ & $17.9 \pm 2.2 \mathrm{~b}$ & $79.9 \pm 18.6 \mathrm{~d}$ & $332.8 \pm 13.6 \mathrm{~d}$ \\
\hline & & \multicolumn{5}{|c|}{ Cadmium content ( $\mu \mathrm{g}$ per plant) } \\
\hline \multirow[t]{3}{*}{29} & 0.25 & $115.7 \pm 14.5 \mathrm{a}$ & $23.0 \pm 4.8 \mathrm{a}$ & $90.2 \pm 19.2 \mathrm{a}$ & $191.6 \pm 17.8 \mathrm{a}$ & $373.5 \pm 25.8 \mathrm{a}$ \\
\hline & 0.50 & $209.5 \pm 21.4 \mathrm{c}$ & $33.7 \pm 6.0 \mathrm{~b}$ & $149.9 \pm 16.5 \mathrm{~b}$ & $531.6 \pm 34.1 \mathrm{c}$ & $902.1 \pm 97.1 \mathrm{c}$ \\
\hline & 0.75 & $65.3 \pm 3.2 \mathrm{e}$ & $5.7 \pm 0.5 \mathrm{e}$ & $43.5 \pm 11.2 \mathrm{f}$ & $426.4 \pm 61.1 \mathrm{~b}$ & $1227.6 \pm 79.3 \mathrm{~d}$ \\
\hline \multirow[t]{3}{*}{93} & 0.25 & $201.4 \pm 9.0 \mathrm{c}$ & $49.9 \pm 3.7 \mathrm{c}$ & $333.5 \pm 25.9 \mathrm{~d}$ & $406.6 \pm 52.4 \mathrm{~b}$ & $629.3 \pm 69.2 \mathrm{~b}$ \\
\hline & 0.50 & $301.2 \pm 27.9 \mathrm{~d}$ & $71.3 \pm 2.1 \mathrm{~d}$ & $656.6 \pm 56.9 \mathrm{e}$ & $666.3 \pm 65.8 \mathrm{~d}$ & $1358.6 \pm 86.9 \mathrm{~d}$ \\
\hline & 0.75 & $161.1 \pm 15.1 \mathrm{~b}$ & $32.4 \pm 6.1 \mathrm{~b}$ & $222.5 \pm 22.3 \mathrm{c}$ & $1467.4 \pm 90.8 \mathrm{e}$ & $1969.0 \pm 85.0 \mathrm{e}$ \\
\hline
\end{tabular}

Data are means \pm standard errors of four replicates. Values in each column followed by the same letter are not significantly different at $P=0.05$ as determined by the Duncan's test. 


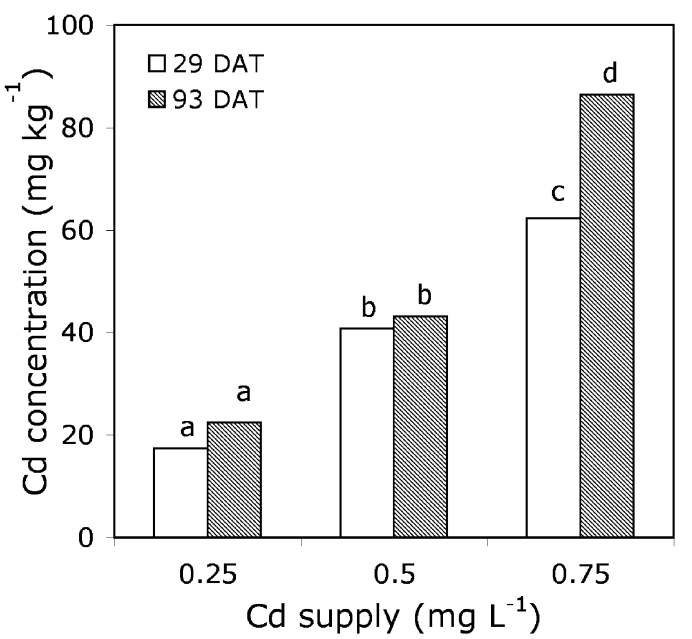

Fig. 3. Cadmium concentration of miscanthus plants treated for 29 and 93 days with different Cd-concentrations $\left(\mathrm{mgl}^{-1}\right)$. Different letters indicate significant differences at $P=0.05$ as determined by the Duncan's test.

whereas that of aboveground plant parts was highest at $0.50 \mathrm{mg}^{-1} \mathrm{Cd}$ and lowest at the highest supply. Between the first and the second harvest, the Cd-concentration of roots, rhizome, and main culm increased only with the highest Cd supply, whereas that of leaves and secondary culms increased with all Cd levels. As a result, at the two lower Cd lev-

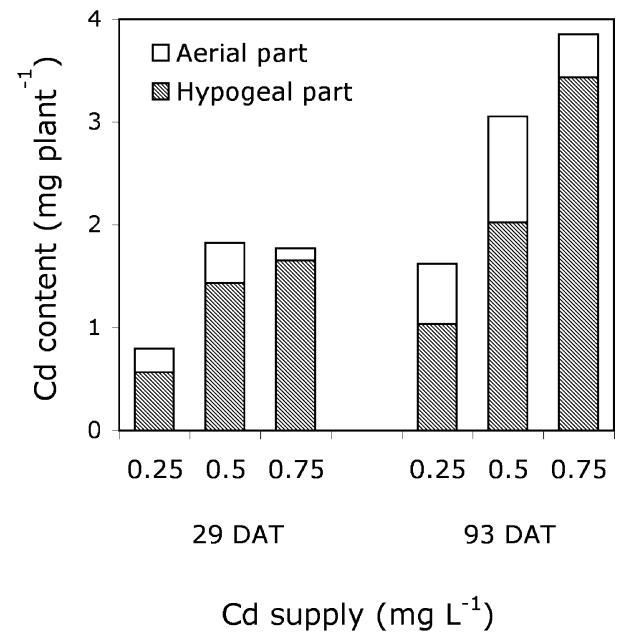

Fig. 4. Cadmium content of miscanthus plants treated for 29 and 93 days with different $\mathrm{Cd}$-concentrations $\left(\mathrm{mg}^{-1}\right)$ and $\mathrm{Cd}$ partitioning between the aerial and hypogeal plant parts. els, the Cd-concentration of the whole miscanthus plant did not change between the first and the second harvest and was $20 \mathrm{mg} \mathrm{kg}^{-1}$ with $0.25 \mathrm{mg} \mathrm{l}^{-1} \mathrm{Cd}$ and $42 \mathrm{mg} \mathrm{kg}^{-1}$ with $0.50 \mathrm{mg} \mathrm{l}^{-1} \mathrm{Cd}$ (Fig. 3). In contrast, with the highest supply, the Cd-concentration increased from 62 to $86 \mathrm{mg} \mathrm{kg}^{-1}$ during the second growth period.

After 1 month of supply, the Cd-content was highest in roots followed, in decreasing order, by rhizome, main culm, secondary culms, and leaves (Table 4).
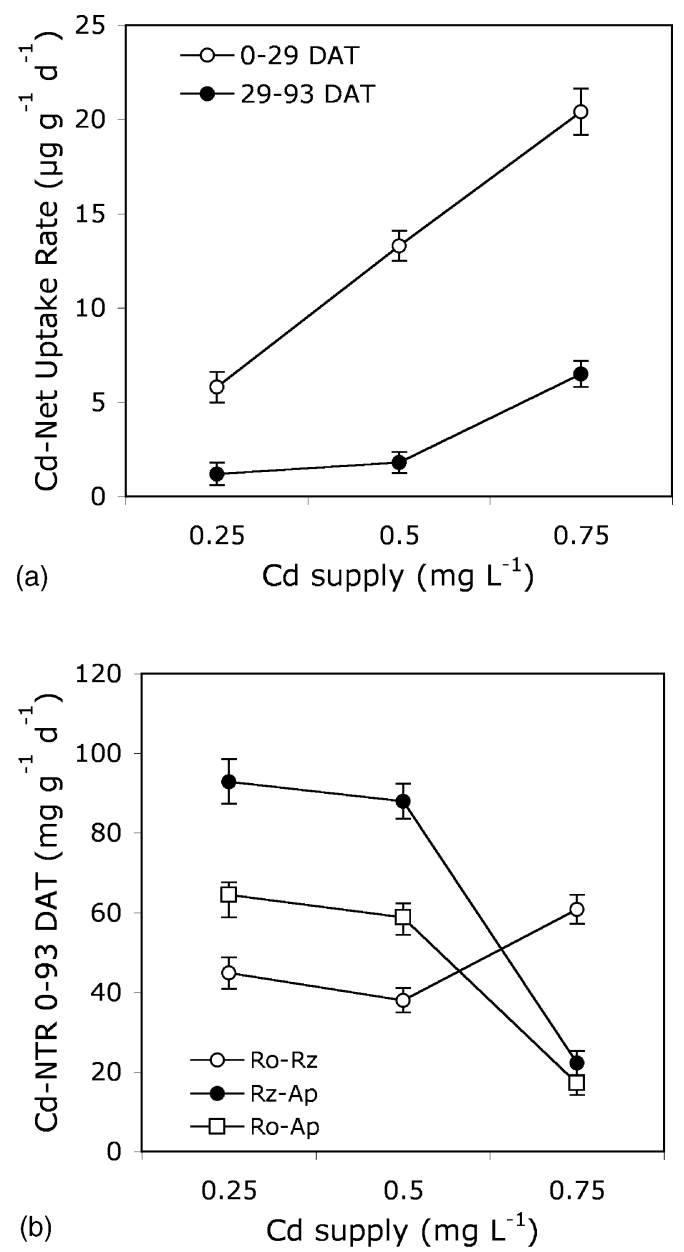

Fig. 5. Net uptake rate (a) of miscanthus plants treated for 29 and 93 days with different Cd-concentrations $\left(\mathrm{mgl}^{-1}\right)$, and net translocation rate (b) from roots to rhizome (Rt-Rm), from rhizome to aerial part (Rm-AP), and from roots to aerial part (Rt-AP) of miscanthus plants treated for 93 days with different cadmium concentrations $\left(\mathrm{mgl}^{-1}\right)$. Bars represent standard errors (S.E.) of four replicates. 
After 3 months, however, the Cd-content of secondary culms was higher than that of the main culm. Roots were the only plant part which Cd-content increased at increasing $\mathrm{Cd}$ supply at both harvests. The Cd-content of rhizome was highest with $0.50 \mathrm{mg} \mathrm{l}^{-1}$ $\mathrm{Cd}$ after the first growth period and with $0.75 \mathrm{mg} \mathrm{l}^{-1}$ $\mathrm{Cd}$ after the second. All aerial plant parts showed the highest $\mathrm{Cd}$-content at the intermediate supply and the lowest at the highest one. Between the first and the second harvest the Cd-content increased in all plant parts. Cadmium partitioning to aboveground plant parts increased with time of exposure but decreased with Cd level (Fig. 4). Thus, after 93 days of treatment, the highest $\mathrm{Cd}$-content of the entire miscanthus plant was obtained with the supply of $0.75 \mathrm{mgl}^{-1}$ and was $3.8 \mathrm{mg}$ per plant, whereas the highest accumulation in the aerial part occurred with the supply of $0.50 \mathrm{mg} \mathrm{l}^{-1} \mathrm{Cd}$ and was $1 \mathrm{mg}$ per plant.

At all Cd levels, the net uptake rate of cadmium was by far higher during the first month of Cd supply than during the following two (Fig. 5a). Values of NUR increased almost proportionally with Cd supply during the first growth period, but increased only between 0.50 and $0.75 \mathrm{mg} \mathrm{l}^{-1} \mathrm{Cd}$ during the second one. Calculated over the whole experiment, the net translocation rate of cadmium within the miscanthus plant slightly decreased between 0.25 and $0.50 \mathrm{mg}^{-1}$ $\mathrm{Cd}$, independently of plant parts (Fig. 5b). Between 0.50 and $0.75 \mathrm{mg} \mathrm{l}^{-1} \mathrm{Cd}$, however, the NTR from roots to rhizome sharpedly increased, whereas those from roots and rhizome to shoot markedly decreased.

\section{Discussion}

In this research, cadmium enhanced miscanthus growth up to $0.50 \mathrm{mgl}^{-1}$ and decreased it at $0.75 \mathrm{mg} \mathrm{l}^{-1}$. Relative growth rates showed that cadmium stimulated growth of all plant parts only during the first month of exposure, whereas during the following 2 months the metal did not affect growth of roots and secondary culms and decreased that of the main culm and the rhizome. Similarly, the growth inhibition recorded with $0.75 \mathrm{mg} \mathrm{l}^{-1} \mathrm{Cd}$ occurred almost exclusively during the first month of supply in all separate plant parts, excepted the main culm. It is worthy to note that during the second growth period, RGRs were by far lower than during the first, irre- spective of treatment and plant part, and that all $\mathrm{Cd}$ levels equally affected growth of miscanthus. It is, therefore, reasonable to suggest that with longer applications the initial growth stimulation observed with Cd-concentrations up to $0.50 \mathrm{mg} \mathrm{l}^{-1}$ could be nullified by a slight inhibition of growth, whereas a partial recovery of growth could occur with $0.75 \mathrm{mg} \mathrm{l}^{-1} \mathrm{Cd}$.

The positive effect on plant growth of low cadmium levels has been poorly discussed in literature, though several authors observed it in experiments lasting between 1 and 11 weeks (Wong et al., 1986; Balsberg-Påhlsson, 1989; Arduini et al., 1994; Gussarsson, 1994). Two possible mechanisms can be suggested. According to Kennedy and Gonsalves (1987) low cadmium levels hyperpolarize the plasma membranes at the root surface, thus increasing the trans-membrane potential, which is an energy source for cation uptake. Moreover, cadmium has been found to induce genes related to mammalian cell proliferation, which could increase growth, though they are also considered responsible for $\mathrm{Cd}$-induced carcinogenesis (Beyersmann, 2002).

Despite of the widely recognized high sensitiveness of roots to heavy metals, in our experiment root biomass was not significantly affected with the highest $\mathrm{Cd}$ supply and showed the highest positive response with the two lower supplies. With $0.75 \mathrm{mgl}^{-1} \mathrm{Cd}$, however, root morphology was dramatically changed, in that dry weight was not affected, but length, surface, and volume were drastically decreased, and root average diameter was increased. These changes are consistent with the hypothesis that $\mathrm{Cd}$ induces an abnormal proliferation of root cells, as suggested by Beyersmann (2002), that is not followed by cell distension, in consequence of the reduction of water flow and mineral uptake (Varga et al., 1999). These changes in root morphology, however, did not affect the efficiency of the root system in supplying nutrients to the shoot, estimated through the index of specific dry weight increment. Indeed, during the first month of treatment no significant differences were observed in the SDWI of Cd-treated and control plants, whereas during the following 2 months cadmium markedly decreased root efficiency, irrespectively of the applied level.

Cadmium affected biomass partitioning between hypogeal organs, in that it markedly increased the allocation of resources to roots rather than to the rhizome. A stronger growth reduction of the rhizome, which 
is a sink for resources that enable shoot resprouting in the following vegetative season, compared to other plant parts was also reported by Balsberg-Påhlsson (1989) in the herbaceous Rosacea, Filipendula ulmaria, in response to cadmium. This phenomenon, that was particularly evident at the two lower $\mathrm{Cd}$ supplies, may be an attempt of the plant to privilege growth of roots in order to counterbalance their reduced efficiency, and is consistent with the hypothesis that also the low $\mathrm{Cd}$ levels used in this experiment may hinder miscanthus growth in a long term.

Cadmium was found to affect negatively both nitrate uptake and its transport from roots to shoot (Sanità di Toppi and Gabbrielli, 1999; Gouia et al., 2000). In our research, however, cadmium neither influenced the net uptake rate of nitrogen nor the $\mathrm{N}$-concentration of different miscanthus parts, during the whole period of treatment. In contrast, the Net Transloction Rate showed that the N-transport within the plant was affected by the metal. The N-NTR from roots to rhizome was drastically reduced with all Cd levels, whereas that from rhizome to aerial part was increased, so that the NTR from roots to aerial part resulted unchanged. It seems that, though cadmium hampered $\mathrm{N}$-transport from roots to rhizome, maybe limiting its flow across the endodermis or its loading into the xylem, miscanthus plants were able to fulfill the nitrogen requirements of the shoot increasing the translocation rate from the rhizome. This again causes a depletion of resources from this plant part.

During the first month of application, the NUR of cadmium was linearly related to the concentration of the metal in the nutrient solution, which is consistent with a passive inflow of cadmium into roots (Arduini et al., 2003). During the following 2 months, Cd-NUR values were appreciable only with $0.75 \mathrm{mg} \mathrm{l}^{-1} \mathrm{Cd}$ suggesting that saturation phenomena limiting Cd-uptake occurred with the two lower levels. Accordingly, the Cd-concentration of the entire miscanthus plant always increased with supply, but only at the highest level with the duration of treatment. These patterns of uptake are consistent with the hypotheses of Salt et al. (1995) that Cd is readily absorbed by plant roots but also that both Cd-binding sites and the transport system saturate at non-toxic levels. In our research, Cd-binding sites had already saturated in roots, rhizome, and main culm after 1 month of treatment with 0.25 and $0.50 \mathrm{mgl}^{-1} \mathrm{Cd}$. This was not the case of leaves and secondary culms which Cd-concentration increased between the two harvests confirming that Cd-transport within the plant is a rather slow process.

The translocation of $\mathrm{Cd}$ to above-ground plant parts is mainly governed by xylem loading, regulated by endodermis, and by xylem flux (Florijn and Van Beusichem, 1993; Schneider et al., 1999). The Cd-concentration of different plant parts showed that the internal transport of cadmium was always greatly restricted in miscanthus and that the translocation to stems and leaves was drastically reduced at $0.75 \mathrm{mg}^{-1}$. The net translocation rate of $\mathrm{Cd}$ from roots to rhizome increased at the highest Cd supply, whereas those from roots and rhizome to the aerial part decreased. These patterns support the hypothesis that Cd-transport within the plant is mainly regulated at the loading step between roots and rhizome, probably at the endodermis level, and that the regulating mechanisms is Cd-sensitive (Schneider et al., 1999). In miscanthus, a critical Cd-concentration is reached in roots grown with $0.75 \mathrm{mg} \mathrm{l}^{-1} \mathrm{Cd}$ after 1 month of treatment, beyond which the ability to retain $\mathrm{Cd}$ in roots is strongly diminished and the metal passively flows into the rhizome. Despite this, the Cd-concentration of stems and leaves does not increase and even decreases, probably for the concurrent drastic decrease of transpiration. In a previous work on miscanthus (Arduini et al., 2003), we found that Cd-translocation from roots to rhizome was severely reduced when $\mathrm{Cd}$ supply was increased from 0.75 to $3 \mathrm{mg} \mathrm{l}^{-1}$ and we suggested that the endodermis barrier was still functioning. However, taking into account present results it was more likely consequence of the drastic decrease of water flow and of all metabolic activities, whereas the slight increase of translocation to the aerial part was due to passive leakage to unsaturated tissues. Present findings are consistent with the conclusions of Hardiman et al. (1989) that, at non-toxic concentrations, Cd-transport to plant top is a function of its concentration in roots, and with the existence of a critical Cd-concentration in roots that causes the breakdown of the endodermis barrier (Florijn and Van Beusichem, 1993; Salt et al., 1995). Above the toxicity threshold, on the other hand, Cd-transport to the above-ground plant parts is restricted in consequence of the severe reduction of water flow within the plant (Haag-Kerwer et al., 1999; Varga et al., 1999; Gouia et al., 2000). According to 
this, the highest Cd-concentrations in plant tops and, therefore, the best phytoextraction results may be obtained with Cd-concentrations immediately below the toxicity threshold.

The total amount of cadmium that can be removed from the substratum is not only function of the Cd-uptake and accumulation in plant tissues but also of plant growth, that is reduced by toxic levels of cadmium, and both processes are dependent on the duration of exposure to the metal. In our research, the Cd-content of all parts of miscanthus increased with increasing exposure to cadmium from 1 to 3 months. Increasing Cd-availability in the nutrient solution always increased the $\mathrm{Cd}$-content of roots but that of the above-ground plant parts only below the toxicity threshold. The patterns of accumulation in the rhizome changed with time of exposure and were similar to those of the aerial part at the first harvest and to that of roots at the second one. This data again confirm our hypothesis that, after 1 month of treatment with $0.75 \mathrm{mg} \mathrm{l}^{-1} \mathrm{Cd}$, cadmium passively flows into the rhizome without any restriction.

In conclusion, the highest Cd-content of the entire miscanthus plant was achieved after 3 months of treatment with $0.75 \mathrm{mg} \mathrm{l}^{-1} \mathrm{Cd}$ and was $3.8 \mathrm{mg}$. However, phytoextraction techniques requires that metals are accumulated in harvestable plant parts that, in miscanthus, are stems and leaves, and also most part of rhizomes if the crop is entirely removed from soil. The highest amount of $\mathrm{Cd}$ accumulated in the above-ground plant parts was $1 \mathrm{mg}$ per plant and was obtained with $0.50 \mathrm{mg} \mathrm{l}^{-1} \mathrm{Cd}$, whereas the Cd-content of rhizome + aerial-part was highest with $0.75 \mathrm{mg}^{-1}$ and was $1.9 \mathrm{mg}$ per plant. These values are not far from those found for other species investigated for phytoextraction purposes (Ebbs et al., 1997; Qian et al., 1999; Klang-Westin and Perttu, 2002) and are, respectively, five and two times those obtained by Arduini et al. (2003) growing miscanthus with higher $\mathrm{Cd}$-concentrations. Obtained values cannot be directly referred to field conditions since soil characteristics (i.e. $\mathrm{pH}$, redox potential, organic matter content, rhizosphere microorganisms, etc.) strongly affect the availability and toxicity of cadmium to plants. Nevertheless, results from hydroponic culture experiments are crucial to highlight the physiological response of plants to toxic and non-toxic levels of cadmium. Further research is needed to investigate the Cd-uptake patterns of miscanthus in the field and to assess whether prolonged applications of low $\mathrm{Cd}$ levels could even be toxic, and thus reduce plant performances.

\section{References}

Arduini, I., Godbold, D.L., Onnis, A., 1994. Cadmium and copper change root growth and morphology of Pinus pinea and Pinus pinaster seedlings. Physiol. Plant. 92, 675-680.

Arduini, I., Masoni, A., 2002. Fitodepurazione. Riv. Agron. 36, 17-32.

Arduini, I., Masoni, A., Ercoli, L., Mariotti, M., 2003. Growth and cadmium uptake of Miscanthus sinensisas affected by cadmium. Agric. Med. 133, 179-188.

Balsberg-Påhlsson, A.M., 1989. Toxicity of heavy metals ( $\mathrm{Zn}, \mathrm{Cu}$, $\mathrm{Cd}, \mathrm{Pb}$ ) to vascular plants. Water Air Soil Pollut. 47, 287-319.

Barbolani, E., Clauser, M., Pantani, F., Gellini, R., 1986. Residual heavy metal $(\mathrm{Cu}$ and $\mathrm{Cd})$ removal by Iris pseudacorus. Water Air Soil Pollut. 28, 277-282.

Beyersmann, D., 2002. Effects of carcinogenic metals on gene expression. Toxicol. Lett. 127, 63-68.

Clark, R.B., 1982. Nutrient solution growth of sorghum and corn in mineral nutrition studies. J. Plant Nutr. 5, 1039-1057.

Ebbs, S.D., Lasat, M.M., Brady, D.J., Cornish, J., Gordon, R., Kochian, L.V., 1997. Phytoextraction of cadmium and zinc from a contaminated soil. J. Environ. Qual. 26, 1424-1430.

Engels, C., 1993. Differences between maize and wheat in growth-related nutrient demand and uptake of potassium and phosphorus at suboptimal root zone temperatures. Plant Soil $150,129-138$.

Ercoli, L., Mariotti, M., Masoni, A., Bonari, E., 1999. Effect of irrigation and nitrogen fertilization on biomass yield and efficiency of energy use in crop production of Miscanthus. Field Crops Res. 63, 3-11.

Florijn, P.J., Van Beusichem, M.L., 1993. Cadmium distribution in maize inbred lines: effects of $\mathrm{pH}$ and level of $\mathrm{Cd}$ supply. Plant Soil 153, 79-84.

Gouia, H., Ghorbal, M.H., Meyer, C., 2000. Effects of cadmium on activity of nitrate reductase and on other enzymes of the nitrate assimilation pathway in bean. Plant Physiol. Biochem. 38, 629-638.

Grant, C.A., Buckley, W.T., Bailey, L.D., Selles, F., 1998. Cadmium accumulation in crops. Can. J. Plant Sci. 78, 1-17.

Greef, M.J., Deuter, M., 1993. Syntaxonomy of Miscanthus × giganteus. Angew. Bot. 67, 87-90.

Gussarsson, M., 1994. Cadsmium-induced alterations in nutrient composition and growth of Betula pendula seedlings: the significance of fine roots as a primary target for cadmium toxicity. J. Plant Nutr. 17, 2151-2163.

Haag-Kerwer, A., Schäfer, H.J., Heiss, S., Walter, C., Rausch, T., 1999. Cadmium exposure in Brassica juncea causes a decline in transpiration rate and leaf expansion without effect on photosynthesis. J. Exp. Bot. 50, 1827-1835.

Hardiman, R.T., Jacoby, B., Banin, A., 1984. Factors affecting the distribution of cadmium, copper and lead and their effect upon 
yield and zinc content in bush beans (Phaseolus vulgaris L.). Plant Soil 81, 17-27.

Hernández, L.E., Lozano-Rodríguez, E., Garáte, A., Carpena-Ruiz, R., 1998. Influence of cadmium on the uptake, tissue accumulation and subcellular distribution of manganese in pea seedlings. Plant Sci. 132, 139-151.

International Agency for Research on Cancer, 1993. Monographs on the evaluation of carcinogenic risks to humans. Beryllium, cadmium, mercury, and exposure in the glass manufacturing industry, vol. 58. IARC, Lyon, France.

Kennedy, C.D., Gonsalves, F.A.N., 1987. The action of divalent zinc, cadmium, mercury, copper and lead on the trans-root potential and $\mathrm{H}^{+}$efflux of excised roots. J. Exp. Bot. 38, 800-817.

Klang-Westin, E., Perttu, K., 2002. Effects of nutrient supply and soil cadmium concentration on cadmium removal by willow. Biomass Bioenergy 23, 415-426.

Kokko, E.G., Volkmar, K.M., Gowen, B.E., Entz, T., 1993. Determination of total root surface area in soil core samples by image analysis. Soil Tillage Res. 26, 33-43.

McLaughlin, M.J., Parker, D.R., Clarke, J.M., 1999. Metals and micronutrients - food safety issues. Field Crops Res. 60, 143163.

Neukirchen, D., Himken, M., Lammel, J., Czypionka-Krause, U., Olfs, H.W., 1999. Spatial and temporal distribution of the root system and root nutrient content of an established Miscanthus crop. Eur. J. Agron. 11, 301-309.

Qian, J.H., Zayed, A., Zhu, Y.L., Yu, M., Terry, N., 1999. Phytoaccumulation of trace elements by wetland plants: III Uptake and accumulation of ten trace elements by twelve plant species. J. Environ. Qual. 28, 1448-1455.
Salt, D.E., Prince, R.C., Pickering, I.J., Raskin, I., 1995. Mechanisms of cadmium mobility and accumulation in Indian mustard. Plant Physiol. 109, 1427-1433.

Salt, D.E., Smith, R.D., Raskin, I., 1998. Phytoremediation. Annu. Rev. Plant Physiol. Plant Mol. Biol. 49, 643-668.

Sanità di Toppi, L., Gabbrielli, R., 1999. Response to cadmium in higher plants. Environ. Exp. Bot. 41, 105-130.

Schneider, T., Haag-Kerwer, A., Maetz, M., Niecke, M., Povh, B., Rausch, T., SchüBler, A., 1999. Micro-PIXE studies of elemental distribution in Cd-accumulating Brassica juncea L. Nucl. Instr. Meth. Phys. Res. B 158, 329-334.

Steel, R.G.D., Torrie, J.H., Dickey, D.A., 1997. Principles and procedure of statistics: a biometrical approach. McGraw-Hill, New York.

Varga, A., Garcinuño Martinez, R.M., Záray, G., Fodor, F., 1999. Investigation of effects of cadmium, lead, nickel and vanadium contamination on the uptake and transport processes in cucumber plants by TXRF spectrometry. Spectrochim. Acta Part B 54, 1455-1462.

Wagner, G.J., 1993. Accumulation of cadmium in crop plants and its consequences to human health. Adv. Agron. 51, 173212.

Wong, M.K., Chuah, G.K., Ang, K.P., Koh, L.L., 1986. Interactive effects of lead, cadmium and copper combinations in the uptake of metals and growth of Brassica chinensis. Environ. Exp. Bot. 26, 331-339.

World Bank Group, 1999. Cadmium. In: The World Bank Group (Ed.), Pollution Prevention and Abatement Handbook 1998. Toward Cleaner Production. WBG, Washington DC, USA, pp. 212-214. 